DOI: $\underline{\text { https://doi.org/10.24867/12GI20Rasevic }}$

\title{
ДИЗАЈНЕРСКО РАЗМИШЉАЫЕ КАО МЕТОДА КРЕАТИВНОГ РЕШАВАЊА ПРОБЛЕМА
}

\section{DESIGN THINKING AS A PROBLEM SOLVING METHOD}

\author{
Ирена Рашевић, Факултет техничких наука, Нови Сад
}

\section{Област:- ИНДУСТРИЈСКО ИНЖЕЊЕРСТВО И ИНЖЕЊЕРСКИ МЕНАЏМЕНТ}

Сажетак - Дизајнерско размишьљьье (енгл. Design Thinking) представља методу у креативном решавању проблема која у центар истраживања поставsа потребе тржишта и потрошача. Предности ове методе је ьена применљивост у свим индустријама, фокусираност на проналажење најбољег решена, односно решења које је у том тренутку најприхватљивије, константно тестирање решења и потрага за могућим унапређењима. Дизајнерско размишљање може представљати алат за управљање иновачијама, али и алат за креативно решавање проблема. Ова метода се успешно комбинује са савременим методама за управљање прочесом иновачија или унапређења прочеса и често је претходница другим методама попут агилних методологија (енгл. Agile) или лина (енгл. Lean). Уз помоћ ове методе, коришћенем конвергентних и дивергентних приступа, односно приступом два дијаманта, добијамо затворени процес у коме се итеративни процеси константно смењују у ииљу унапређењ а прочеса, услуге, производа или решавања одређеног проблема.

Кључне Речи: Дизајнерско размишљање, управљање иновачијама, управљање креативношћу, управљање пројектима.

Abstract - Design Thinking is a method in creative problem solving that puts the needs of the market and consumers at the center of research. The advantages of this method are its applicability in all industries, focus on finding the best solution, ie the solution that is most acceptable at that time, constant testing of solutions and the search for possible improvements. Design thinking can be a tool for innovation management, but also a tool for creative problem solving. This method is successfully combined with modern methods for managing the process of innovation or process improvement and is often a precursor to other methods such as agile methodologies or Lean. With design thinking method, using convergent and divergent approaches, the approach of two diamonds, we get a closed process in which iterative processes are constantly changing in order to improve the process, service, product or solve a particular problem.

Keywords: Design Thinking, Managing Innovation, Managing Creativity, Project Management.

\footnotetext{
Напомена:

Овај рад проистекао је из мастер рада чији ментор је био др Петар Врговић, ванр. проф.
}

\section{1. УВОД}

Овај рад настоји да одговори на питања која се тичу дизајнерског размишљања као методе креативног решавања проблема и управљања иновацијама. Истраживачка питања која се могу поставити су следећа:

1.Шта је дизајнерско размишљање?

2.Какве проблеме може да реши дизајнерско размишљање?

3.Да ли је дизајнерско размишљање компатибилно са другим методама за управљање иновацијама?

4.Да ли је дизајнерско размишљање структурисан метод креативног размишљања?

5.На који начин се дизајнерско размишљање може користити у индустрији?

6.Какве су разлике између приступа дизајнерског размишљања?

\section{2. ДИЗАЈНЕРСКО РАЗМИШЉАЊЕ}

Иако сам појам и методологија дизајнерског размишљања датира од 1978. године [1], почетак свог успона доживљава 2005. године, када почиње да се изучава на Станфорду [2] на докторским студијама као методологија креативног решавања проблема, а након тога научни истраживачи [3] и инжењери [4] у индустрији почињу да озбиљније истражују ову методологију, па чак и да развијају своју.

Иако је дизајнерско размишљање није једна од најчешће коришћених методологија креативног решавања проблема, постоји више приступа дизајнерског размишљања.Дизајнерско размишљање представља један од модерних приступа у креативном решавању проблема.

Први модел дизајнерског размишљања је ИДЕО модел. Тим Браун и његов тим дизајнерско размишљање описују као иновациони приступ у чијем је центру човек и који интегрише дизајнерске алате са људским потребама, могућностима технологијама и захтевима који су неопходни за успех пословног подухвата.

У својој књизи „Промена уз помоћ дизајна“ Тим Браун наводи да се дизајнерско размишљање налази у пресеку три битне ставке и то су:

- Пожељност,

- Одрживост, и

- Изводљивост [5].

Слика 1 на Веновом дијаграму приказује три наведене ставке и позицију дизајнерског размишљања. 


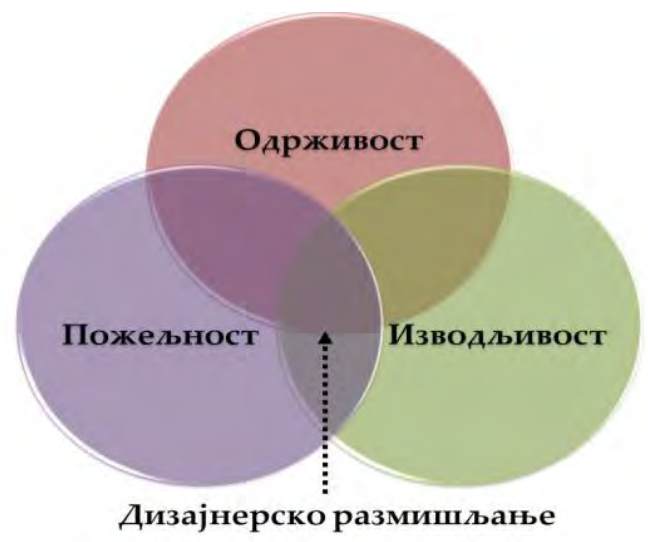

Слика 1: Позиција дизајнерског размишљања по моделу ИДЕО

Извор: Аутор према (Brown 2009) [5]

Такође, дизајнерско размишљање по ИДЕО моделу, користи наизменично дивергентно и конвергентно размишљање. Значај оваквог приступа је велики приликом генерисања идеја и одабира истих. Када се користи техника дивергентног размишљања, тада се прикупљају и стварају идеје, док се техника конвергентног размишљања користи за сужавање избора и доношење одлука.

Идеов модел дизајнерског размишљања представљен у књизи Тима Брауна има три кључне активности које се непрекидно смењују и то су :

Инспирација,

Идејација, и

Имплементација. [5]

Други модел дизајнерског размишљања је ИБМ модел. Овај модел, односно радни оквир дизајнерског размишљања карактерише аспект са три кључна става, а сваки од њих има три артефакта и то су према ИБМ :

- Принципи - има 3 артефакта и то су:

- Фокус на корисничким исходима, (прем енгл. focus on user outcomes),

- Непрекидне иновације, (према енгл. restless reinvention), и

- Диверсификовани тимови. (према енгл. Diverse Team).

- Петља, такође има три артефакта и то су:

- Опсервација, (према енгл. Observe),

- $\quad$ Рефлекција, (према енгл. Reflect), и

- $\quad$ Тестирање или прављење. (према енгл.Make).

- Кључеви - као и претходна два става има три артефакта и то су:

- Брда, (према енгл. Hills),

- Понављања, (према енгл. Playbacks), и

- Корисник спонзор. (према енгл. User Sponsor). [4]

Трећи и последњи модел дизајнерског размишљања у овом раду је модел Џејн Лидке, професора универзитета у Вирџинији. Професорка Лидка спада у ред најеминентнијих стручњака из области дизајнерског размишљања и у својим радовима је приказала структурисани модел дизајнерског размишљања. Структурисани модел дизајнерског размишљања Џејн Лидке има два дела и то:

- Четири питања, и
- Десет алата дизајнерског размишљања [6].

Четири питања треба да буду водичи кроз цео процес дизајнерског размишљања и да усмерава тим кроз цео процес. Питање „Шта је?“ треба да да одговор какво је тренутно стање које треба да се мења или какав је тренутни проблем који треба да се реши. Питањем „Шта ако?““ треба да се постави могући сценарио и правци решавања садашњег проблема. Прва два питања представљају процес утврђивања садашњег и будућег стања, као и процес стварања нових идеја. Одговорањем на питање „Шта изазива вау ефекат?“ долази до унапређења идеје и тестирања валидности идеје. Последње питање у овом моделу је „Шта ради“ и одговарањем на ово питање долази се до валидације саме идеје

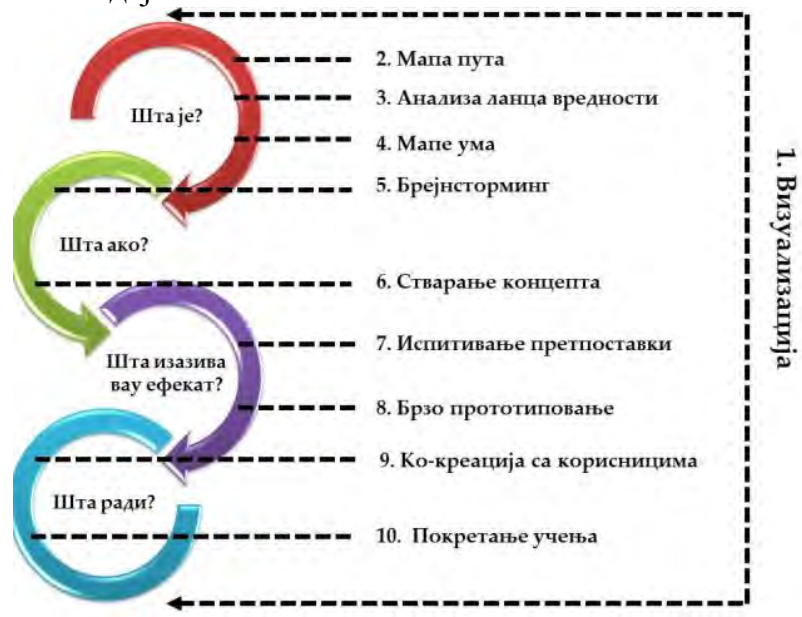

Слика 5: Дизајнерски алати у структурисаном моделу дизајнерског размишљања

Извор: Аутор према (Liedtka, King / Benett 2013) [6]

\section{4. СТУДИЈЕ СЛУЧАЈА}

ИБМ је објавила своју студију случаја у фебруару 2018. године и приказала директан утицај дизајнерског размишљања на пројекте, односно проблеме које треба да реше са аспекта економских показатеља. Приоритет ИБМ су биле следеће ставке:

Квантитативни показатељи који су праћени су:

- Брзина изласка на тржиште,

- Смањење времена дизајнирања производа,

- Смањење времена развоја производа,

- Повраћај инвестиције [7].

Када су у питању трошкови унутар компаније, износили су 6.8 милиона долара и то 159 хиљада долара по мањем пројекту и 1.5 милион долара по великом пројекту. Трошкови трансформације компаније коштали су 5 милиона долара, док су трошкови тренинга били 218 хиљада долара. Дакле укупни трошкови су износили нешто више од 12 милиона долара. Ови трошкови су бележени током три године.

Приход на основу бржег дизајнирања производа и развоја производа 20.6 милиона долара, током три године. Приход на основу већег портфолија је био 18.6 милиона долара, такоше током три године. Приход на основу уравнотежења процеса у организацији износио је 9.2 милиона долара у току три године. На основу прихода и трошкова може се израчунати процентуално повраћај инвестиције, 
односно RoI (енгл. Return of Investment) у току три године. Први корак јесте израчунавање нето прихода на основу следеће формуле:

$$
\text { Нето приход }=\frac{48.400 .000 \$}{12.018 .000 \$}=36.382 .000 \$
$$

Други корак у израчунавању повраћаја инвестиције се рачуна на основу следеће формуле:

$$
\text { Повраћај инвестиције }=\frac{36.382 .000 \$}{12.018 .000 \$}=3.03
$$

На основу наведене формуле долази се до закључка да је сваки долар уложен у имплементацију дизајнерског размишљања донео 3.03 долара, односно да је повраћај саме инвестиције $303 \%$

Почетком двадесет и првог века Банка Америке је решила да привуче нове коринике да отварају рачун у њој. Ова банка, једна од највећих инвестиционих банака у Америци, након донете одлуке 2004. године, ангажује ИДЕО агенцију, како би могли да поставе проблем и реше га на другачији начин.

Банка је желела другачији приступ, јер иновација у индустрији која иновације не користи као извор конкурентске предности, може донети значајно боље позиционирање на тржишту. Решили су да спроведу етнографска истраживања код људи између 35 и 50 година. Посматране су породице у Атланти, Балтимору и Сан Франциску.

Истраживачи су добили могућност да погледају један такав дневник код жене у Атланти, увидели су да су жене заокруживале износе на најближу цифру, на пример, уместо 49.65\$ писале су 50\$. Иако је овај приступ поједноставио прорачун, ипак је допринео већој потрошњи него што је било потребно. Друго сазнање добијено из овог истраживања је неспособност мајки да штеде, било да је разлог да немају довољно новца или импулсивна куповина. Тако је откривен кључни детаљ који је могао да створи нову вредност за клијенте и банку.

Након што је покренута опсежна маркетиншка кампања у Њујорку, виђени су ефекти дизајнерског размишљања. Банка Америке је након свих тестирања покренула програм услуге ,задржите промену“ крајем 2005. године. Банка Америке је имала следеће бенефите:

- Милион нових корисника за мање од годину дана од почетка пружања нове услуге.

- Више од 12 милиона корисника нове услуге.

- Захваљујући новој услузи, уштедело се више од 2 милијарде долара.

- $60 \%$ свих нових купаца жели услугу задржите промену.

- $99 \%$ је одлучило да задржи ту врсту услуге [8].

Ова врста услуге је омогућила Банци Америке да генерише више послова за своје програме штедње и да се боље позиционира као инвестициона банка.

Данска општина Холстебро је 2007. године имала проблем са услугом народне кухиње. Данска, као многе развијене државе, има субвенционисане оброке за своје најстарије грађане и достављају оброке оним људима који пате од смањене радне способности због болести, старости или других услова. Проблем се састојао у томе да је велики број старих лица, који су корисници ове услуге, имали лош квалитет живота и прехрамбене изазове, јер су се премало хранили. Холстебро општина је одлучила да ангажује Хеч и Блум компанију, како би истражили корен проблема. Хеч и Блум су открили да се готово 60\% старијих особа које користе ову услугу имају веома лошу исхрану, док је око 20\% било неухрањено. [6] Ефекти овог проблема су имали веће финансијско оптерећење буџета, услед честог оболевања старих људи услед неухрањености. Агенција Хеч и Блум је решила да приступи решавању проблема на другачији начин. Кренули су од интервјуисања старијих особа, не би ли открили још неки скривени проблем. Осим интервуја, агенција је истраживала понашање, потребе и жеље старијих, користећи свеобухвтни истраживачки процес, како би се усредсредили на откривање узрока тренутне ситуације и неисказаних потреба.

Чланови агенцијиног истраживачког тима, посматрали су запослене у прехрамбеној служби који су припремали и достављали храну старијим особама. Поред посматрања запослених, посматрани су и корисници који су прекинули да користе ову услугу, као и људе близу старосне границе за пензионисање, који би могли да се квалификују за субвенционисани оброк. Цео процес био је опсежан и захтевао је да се обави много разговора, те су тако интервјуисани и супервизори процеса припреме хране на радном месту. Тај део пројекта је заправо био кључан за откривање целокупног проблема. Тим људи који је радио на пројекту схватио је да поставка проблема је погрешна и да није кључ решења у интервјуисању корисника, већ да се морају интервјуисати и радници у кухињи. Радници у кухињи су били главни и покретачки чинилац проблема који се требао решити. Разлози зашто су радници у кухињи били покретачки чинилац проблема су следећи:

- Посао у јавној кухињи је посао са ниским статусом у Данској,

- Лоша перцепција о људима који тамо раде.

- Незадовољно особље.

Цео процес је утицао на промену идентитета јавне кухиње. Резултат стварања оваквог јеловника је повећао потражњу за одређеним јелима и то до 8 пута више него раније. Радници у јавној кухињи су имали одрешене руке да унапреде јеловник на основу сазнања које су добијали од старијих људи из њихове околине. Возачи који достављају оброке, су почели да комуницирају са старијим лицима тако што су коришћене канбан картице за комуникацију. На тај начин комуникација се значајно унапредила из следећих разлога:

Омогућава повратну информацију запосленима о квалитету услуге.

- Купци добијају информације о начину спремања хране и предлоге како да их додатно припреме.

- Коментари читани на глас на састанцима особља су позитивно деловали на мотивацију запослених.

- На основу ових картица, стари људи су имали утисак да доприносе развоју услуге. [6]

Јавна кухиња је покренула и издавање новина у којима су биле садржане информације о запосленима, њихове приче, слике са догађаја и слично. 
Када је трансформација услуге јавне кухиње извршена, реорганизацијом јеловника и побољшањем описа оброка, повећања је за више од $500 \%$ за мање од недељу дана. Након три месеца број купаца је скочио са 650 на 700 корисника. Осим квантитативних показатеља, видљиви су били помаци у мотивацији запослених, као и перцепцији о себи и свом послу.

\section{5. ЗАКЉУЧАК И ДАЉИ ПРАВЦИ ИСТРАЖИВАЊА}

Вештина креативног решавања проблема у последњој деценији представља једну од најцењенијих пословних вештина коју цене послодавци. Разлог је тај што је интернет у последњих двадесет и пет година радикално променио тржиште и изнедрио нове пословне моделе, који захтевају нове пословне вештине. Многе савремене компаније имају устаљене и прецизиране методе за креативно решавање проблема, а неке од њих су судар мозгова, размишљајући шешири, Делфи метод и слично. Ипак, нови модели пословања, захтевају и другачије приступе од оних устаљених, те се одређене компаније одлучују за другачије методе за креативно решавање проблема.

Дизајнерско размишљање, за разлику од судара мозгова и размишљајућих шешира, представља у исто време и метод и алат за креативно решавање проблема, али и приступ за вођење пројеката. Дизајнерско размишљање као метод креативног решавања проблема се усредсређује на проблеме корисника, односно представља метод који у центар свог истраживања ставља човека. Кроз посматрање три различита приступа у дизајнерском размишљању, закључује се да дизајнерско размишљање има итеративни и континуалан приступ. У дизајнерском размишљању се константно примењују дивергентно и конвергентно размишљање. Такође се кроз цео процес дизајнерског размишљања стварају и тестирају нове идеје, а затим се кроз интеракцију са корисницима испитује изводљивост, а све у циљу унапређења производа или услуге, односно квалитетног решавања проблема. Студије случаја су приказале то да је дизајнерско размишљање веома ефикасан метод за креативно решавање проблема, било да се ради о социјалном проблему, ИТ индустрији, финансијама и тако даље. Осим што дизајнерско размишљање може да допринесе снижењу трошкова, може значајно да повећа профит компанији, што је видљиво на примеру ИБМ, где је главни фокус био на снижењу трошкова, док су пратећи ефекти били повећање профита, брзина изласка на тржиште и сл.

Осим тога, дизајнерско размишљање такође може да омогући стварање иновација и омогући компанији могућност дистанцирања од конкуренције, што је видљиво на примеру Банке Америке. Као нуспојава иновирања услуге, Банка Америке има 12 милиона корисника те услуге и штедни капитал који износи више од 2 милијарде долара.

Такође дизајнерско размишљање може да допринесе решавању социјалних проблема, као што је то видљиво у случају општине Холстебро, где је фокус био на унапређењу задовољства старијих особа и подизању свести о радницима запосленим у јавној кухињи, а као додатни бенефит, остварена је повећана тражња за јелима из јавне кухиње за 500 процената.

Што се тиче даљих праваца истраживања они би могли би бити у смеру активне едукације компанија у Србији о употребљивости дизајнерског размишљања као методи креативног решавања проблема и оснивања центра за дизајнерског размишљања на факултету, као што је то учињено на Универзитету Вирџинија, где се могу организовати предавања и консултантске активности, како би наше компаније могле да буду још конкурентније на међународном тржишту.

Могућа ограничења у даљем истраживању овог проблема могу бити мала заступљеност компанија у Р. Србији које користе дизајнерско размишљање као метод креативног решавања проблема, те квантитативно истраживање је тренутно веома тешко урадити, услед малог узорка и незаинтересованости компанија да учествују у истраживању.

\section{6. ЛИТЕРАТУРА}

[1] https://designthinking.ideo.com/history септембар 2020.

[2] https://dschool.stanford.edu/fellows-inresidence/project-fellowship-history-approach септембар 2020

[3] J. Liedtka \& T. Oglivie: Design for growth: A design thinking toolkit for managers. Columbia University Press, 2011.

[4] https://www.ibm.com/design/thinking/page/framework септембар 2020.

[5] T. Brown: Change by Design - How Design Thinking Transforms Organisations and Inspires Innovation. Harper Collins, 2009.

[6] J. Liedtka, A. King, \& K. Benett: Solving problem with design thinking. New York: Columbia University Press, 2013

[7] Forrester: How IBM Drives Client Value And Measurable Outcomes With Its Design Thinking Framework. Business Report, Forrester Research, Inc., February, 2018

[8] https://thisisdesignthinking.net/2018/09/feeling-incontrol-bank-of-america-helps-customers-to-keep-thechange/ Октобар 2020.

\section{Кратка биографија:}

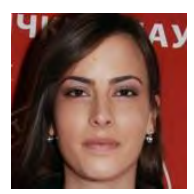

Ирена Рашевић рођена је у Горњем Милановцу 1993. године. Дипломски рад из области финансијског менаџмента одбранила на Факултету техничких наука у Чачку у септембру 2016. године. На Факултету техничких наука из области индустријског инжењерства и менаџмента одбранила мастер рад у октобру 2020. године. Објавила 5 научних радова. Има више од 2 година искуства у продаји и услугама. Области интересовања су јој управљање креативношћу и утицај мотивације на креативност.

Контакт: irenarasevic@yahoo.com irenarasevic@uns.ac.rs 